\title{
PENGARUH EKSPOR DAN IMPOR TERHADAP CADANGAN DEVISA DI INDONESIA
}

\author{
BINTI KHOIRUL MAHMUDAH \\ Fakultas Ekonomi dan Bisnis, Jurusan Ekonomi Syariah, \\ Institut Agama Islam Negeri (IAIN) Salatiga \\ bintikhoirulmahmudah132@gmail.com
}

\begin{abstract}
This study aims to analyze the amount of foreign exchange reserve in Indonesia. And the effect of exsports and imports on foreign exchange reserve in Indonesia. This data usade are secondary data derived from The Central Statistics Agency and Indonesian Banks. This research uses a quantitative analysis. Analysis to see whether the exsport and import factors significantly affect the foreign exchanges reserves in indonesia. Based on the regresion result in the know that exports have a positive and significant impact on Indonesian,s foreign exchange reserve while imports have a negative and significant impact on indonesian,s foreign exchange reserve.
\end{abstract}

Key Words : Exsport, Import, Foreign Exchange Reserve

\section{PENDAHULUAN}

\section{Pendahuluan}

Perdagangan internasional adalah pengukuran yang baik untuk permintaan cadangan devisa. Variabilitas perdagangan internasional sangat bergantung kepada ekspor dan impor suatu negara. Suatu negara sangat mengharapkan tingkat eksporyang tinggi jika dibandingkan dengan impornya, kondisi ini akan membuat cadangan devisa akan mengalami peningkatan yang sangat efektif dan efisien. Selain itu cadangan devisa juga dapat digunakan untuk menjaga nilai tukar yang

menguntungkan untuk pertumbuhan ekspor dan banyak lagi aliran FDI di Indonesia. Menurut IMF (2003).

Tujuan utama dari cadangan devisa adalah untuk memfasilitasi pemerintah dalam melakukan intervensi pasar, sebagai upaya untuk menstabilkan nilai tukar. Terkhusus dalam rangka mengoptimalkan cadangan devisa Bank Indonesia senantiasa menekankan pentingnya aspek kelola yang baik. Di Indonesia pengaturan mengenai lembaga yang berwenang untuk mengatur dan mengelola cadangan devisa ditetapkan dalam Undang-Undang tentang Bank Indonesia No.23 Tahun 1999 sebagaimana yang direvisi menjadi Undang-Undang No.3 Tahun 2004. Berdasarkan pasal 13 undang-undang tersebut, kepada Bank Indonesia dalam rangka melaksanakan kebijakan moneter diberi wewenang untuk mengelola cadangan devisa. Dalam pengelolaan cadangan devisa tersebut, Bank Indonesia dapat melakukan transaksi devisa dan dapat menerima pinjaman (Gandhi,2006:7).

Secara umum, perkembangan cadangan devisa yang dimiliki oleh Indonesia dari tahun 1990 hingga 2014 mengalami nilai yang fluktuatif. Saat krisis ekonomi tahun 1997 cadangan devisa Indonesia mengalami penurunan sebesar $17.486,80$ juta US\$ dan pada tahun 2005 cadangan devisa Indonesia mengalami penurunan kembali sebesar 34.723,69 juta US\$ yang disebabkan oleh tingginya harga minyak dunia sebesar US\$ 68/barel. Sedangkan untuk tahun 2012 cadangan devisa Indonesia mengalami nilai yang paling tinggi jika dibandingkan dengan tahun-tahun sebelumnya sebesar112.781,00 juta US\$. Dimana peningkatannya empat kali lipat jika 
dibandingkan dengan tahun 2005. Namun, pada tahun 2013 mengalami penurunan jika dibandingkan dengan tahun 2012 sebesar 99.387,00 juta US\$. Adapun alasan naik turunnya jumlah cadangan devisa Indonesia dari tahun 1990 sampai 2014, dikarenakan adanya peningkatan pengeluaran pemerintah dalam rangka pembayaran utang luar negeri.Pembayarautang luar negeri disebabkan karena adanya pinjaman dari badan-badan keuangan internasional yang salah satunya adalah IMF selaku Dana moneter nasional.

\section{Tujuan Penelitian note}

Penelitian ini bertujuan untuk mengetahui pengaruh ekspor, impor terhadap cadangan devisa di Indonesia, untuk mengetahui pengaruh secara signifikan antara ekspor dan impor terhadap cadangan devisa Indonesia.

\section{KERANGKA PEMIKIRAN}

\section{Cadangan Devisa}

Cadangan devisa didefinisikan sebagai seluruh aktiva luar negeri yang dikuasai oleh otoritas moneter dan dapat digunakan setiap waktu, guna membiayai ketidakseimbangan neraca pembayaran atau dalam rangka stabilitas moneter dengan melakukan intervensi di pasar valuta asing dan untuk tujuan lainnya. Berdasarkan definisi tersebut menfaat cadangan devisa yang dimiliki oleh suatu negara dapat dipergunakan untuk menjaga kestabilan nilai tukar dan dapat dipergunakan untuk membiayai defisit pada neraca pembayaran Di dalam perkembangannya, ekonomi nasional Indonesia dikenal dua terminologi cadangan devisa, yaitu official foreign exchange reserve dan country foreign exchange reserve, yang masing-masing mempunyai cakupan yang berbeda. Pertama, merupakan cadangan devisa milik negara yang dikelola, diurus, dan ditatausahakan oleh bank sentral, sesuai dengan tugas yang diberikan oleh UU No. 13 Tahun 1968. Kedua, mencakup seluruh devisa yang dimiliki badan, perorangan, lembaga, terutama lembaga keuangan nasional yang secara moneter merupakan bagian dari kekayaan nasional (Halwani, 2005 dalam Juniantara, 2011:34).

\section{Ekspor}

Kegiatan perdagangan internasional yang memberikan rangsangan guna memenuhi permintaan dalam negeri yang menyebabkan tumbuhnya industri-industri pabrik besar, bersamaan dengan struktur politik yang stabil dan lembaga sosial yang fleksibel. Berdasarkan uraian di atas, terlihat bahwa ekspor mencerminkan aktivitas perdagangan antarbangsa yang dapat memberikan dorongan dalam dinamika pertumbuhan perdagangan internasional, sehingga suatu negara-negara yang sedang berkembang kemungkinan untuk mencapai kemajuan perekonomian setaraf dengan negara-negara yang lebih maju.

Ekspor adalah pembelian negara lain atas barang buatan perusahaan-perusahaan di dalam negeri. Faktor terpenting yang menentukan ekspor adalah kemampuan dari Negara tersebut untuk mengeluarkan barang-barang yang dapat bersaing dalam pasaran luar negeri. (Sukirno, 2008: 205). Ekspor akan secara langsung mempengaruhi pendapatan nasional. Akan tetapi, hubungan yang sebaliknya tidak selalu berlaku, yaitu kenaikan pendapatan nasional belum tentu menaikkan ekspor oleh karena pendapatan nasional dapat mengalami kenaikan sebagai akibat dari kenaikan pengeluaran rumah tangga, investasi perusahaan, pengeluaran pemerintah dan penggantian barang impor dengan barang buatan dalam negeri. (Sukirno, 2008:206). Ekspor neto merupakan selisih antara ekspor total dengan impor total suatu negara. Apabila nilai ekspor neto positif, berarti nilai ekspor lebih besar dari nilai impor dan apabila nilai ekspor neto negatif, berarti nilai ekspor lebih kecil dari nilai impor.

\section{Impor}

Impor dapat diartikan sebagai pembelian barang dan jasa dari luar negeri ke dalam negeri dengan perjanjian kerjasama antara 2 negara atau lebih. Impor juga bisa dikatakan sebagai perdagangan dengan cara memasukkan barang dari luar negeri ke wilayah Indonesia dengan memenuhi ketentuan yang berlaku. 
Impor adalah proses transportasi barang atau komoditas dari suatu negara ke negara lain secara legal, umumnya dalam proses perdagangan. Proses impor umumnya adalah tindakan memasukan barang atau komoditas dari negara lain ke dalam negeri. Impor barang secara besar umumnya membutuhkan campur tangan dari bea cukai di negara pengirim maupun penerima. Impor adalah bagian penting dari perdagangan internasional. Kegiatan impor dilakukan untuk memenuhi kebutuhan rakyat. Produk impor merupakan barang-barang yang tidak dapat dihasilkan atau negara yang sudah dapat dihasilkan,tetapi tidak dapat mencukupi kebutuhan rakyat.

\section{Kerangka Pemikiran}

Terjadi hubungan antara ekspor, impor terhadap penyaluran kredit. Dengan demikian dapatdirumuskan kerangka pikir penelitian sebagai berikut :

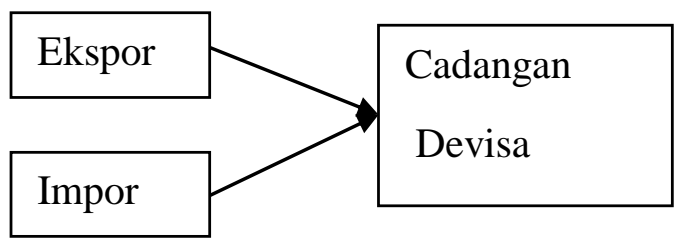

\section{Hipotesis}

Hipotesis dalam penelitian ini sebagai berikut:

1. Ekspor berpengaruh secara signifikan terhadap Cadangan devisa di Indonesia.

2. Impor berpengaruh secara signifikan terhadap Cadangan devisa di Indonesia.

3. Ekspor dan Impor bersama-sama berpengaruh secara signifikan terhadap Cadangan devisa di Indonesia

\section{METODE PENELITIAN}

\section{Jenis dan Sumber data}

Jenis data yang digunakan dalam penelitian ini adalah data sekunder yang diperoleh dari berbagai sumber, antara lain yang diperoleh dari Statistik Ekonomi Moneter Indonesia (Bank Indonesia), Badan Pusat Statistik (BPS), jurnaljurnal ilmiah, serta literatur-literatur lain yang berkaitan dengan topik penelitian ini. Data yang digunakan dalam penelitian ini adalah data time series. Data tersebut diolah kembali sesuai dengan kebutuhan model yang digunakan.

\section{Metode Analisis}

Penelitian ini menggunakan metode analisis ekonometrika. yaitu model regresi berganda dengan metode kuadrat terkecil sederhana OLS (Ordinary Least Square). Penaksiran OLS merupakan penaksiran tak bias linear yang terbaik (best linear unbiased estimator/BLUE). Fungsi persamaan umum yang akan diestimasi dalam penelitian ini adalah:

$$
\mathrm{CD}=\beta_{\mathrm{o}}+\beta_{1} \mathrm{X}+\beta_{2} \mathrm{M}+\mathrm{e}
$$

Metode yang digunakan dalam penelitian ini adalah logaritma berganda. Persamaan regresi ditransformasikan ke logaritma berganda dengan menggunakan logaritma natural (ln), logaritma terhadap basis e. variabel-variabel yang masih bersatuan milyaran rupiah di transformasikan kedalam satuan persen (\%). model ini merupakan model regresi linear karena variabel $\mathrm{Y}, \mathrm{X}_{1}$ dinyatakan dalam bentuk logaritma. karena bentuk linearitasnya, maka model ini disebut logganda atau log linear. Persamaan diatas ditransformasikan dalam bentuk log sehingga menjadi linear:

$$
\ln C D=\beta_{0}+\beta_{1} \ln X+\beta_{2} \ln M+e
$$

Keterangan:

$\operatorname{lnCD}=$ nilai cadangan devisa

$\ln \mathrm{X}=$ nilai Ekspor

$\operatorname{lnM}=$ nilai Impor

e $\quad=$ kesalahan yang disebabkan oleh faktor acak

$\beta_{1}, \beta_{2},=$ koefisien regresi sekaligus koefisien elastisitas

\section{Definisi Variabel}

Penelitian ini menggunakan satu variabel terikat dan dua variabel bebas. Definisi operasional masing-masing variabel dalam penelitian ini adalah sebagai berikut :

1. Ekspor

Ekspor adalah penjualan komoditi ke negara lain dengan mengharapkan 
pembayaran dalam bentuk valuta asing. Dinyatakan dalam Juta USD.

2. Impor

Perdagangan dengan cara memasukkan barang dari luar negeri ke dalam wilayah Indonesia dengan memenuhi ketentuan yang berlaku. Dinyatakan dalam Juta USD.

3. Cadangan Devisa

Cadangan devisa merupakan stok mata uang asing yang dimiliki suatu negara dan disimpan oleh bank sentral yang dapat digunakan untuk transaksi atau pembayaran internasional. Diukur dalam Milliar USD.

\section{Uji Signifikansi simultan (Uji F)note}

Nilai $F_{\text {hitung }}$ digunakan untuk menguji ketepatan model. Uji F ini juga sering disebut sebagai uji simultan, untuk menguji apakah variabel bebas yang digunakan dalam model mampu menjelaskan perubahan nilai variabel tergantung atau tidak. Untuk menyimpulkan model masuk dalam kategori cocok (fit) atau tidak, kita harus membandingkan nilai $F_{\text {hitung }}$ dengan nilai $F_{\text {tabel }}$ dengan derajat kebebasan: df: a, (k-1), (n-k). Nilai $F_{\text {hitung dapat diperoleh }}$ dengan rumus:

$$
F_{\text {hit }}=\frac{\mathrm{R}^{2} / \mathrm{k}}{\left(1-\mathrm{R}^{2}\right) /(\mathrm{n}-\mathrm{k}-1)}
$$

Dimana :

$\mathrm{F}=$ Nilai $\mathrm{F}_{\text {hitung }}$

$\mathrm{N}=$ Jumlah observasi

$\mathrm{R}^{2}=$ Koefisien determinasi

$\mathrm{K}=$ Jumlah variable

Hipotesis yang digunakan adalah :

$H_{\mathrm{o}}: \beta_{\mathrm{i}}=0$ Semua variabel bebas tidak berpengaruh terhadap variabel bebas secara bersama-sama

$\mathrm{H}_{1}: \beta_{\mathrm{i}} \neq 0$ Semua variabel atau minimal salah satu variabel berpengaruh terhadap variabel terikat secara bersama-sama

\section{Uji signifikansi parameter (uji t)note}

Nilai thitung digunakan untuk menguji apakah variabel tersebut berpengaruh secara signifikan terhadap variabel tergantung atau tidak. Suatu variabel akan memiliki pengaruh yang berarti jika nilai $t_{\text {hitung }}$ variabel tersebut lebih besar dibandingkan dengan nilai $t_{\text {tabel }}$. Untuk menghitung nilai thitung digunakan rumus:

$$
t_{i}=\frac{b j}{S b j}
$$

Keterangan:

$\mathrm{t}=$ Nilai $\mathrm{t}_{\text {hitung }}$

$\mathrm{bj}=$ Koefisien regresi

$\mathrm{sbj}=$ Kesalahan baku koefisien regresi.

Hipotesis yang diuji pada uji statistik $\mathrm{t}$ adalah sebagai berikut :

$\mathrm{H}_{0}: \beta_{\mathrm{i}}=0$ Tidak ada pengaruh yang signifikan antara variabel bebas terhadap variabel terikat.

$\mathrm{H}_{1}: \beta_{\mathrm{i}} \neq 0$ Ada pengaruh yang signifikan antara variabel bebas terhadap variabel terikat

\section{Uji koefisiensi determinasi $\left(\mathbf{R}^{\wedge} \mathbf{2}\right)$ note}

Nilai $R^{2}$ disebut juga koefisien determinasi. Koefisien determinasi bertujuan untuk mengetahui seberapa jauh kemampuan model regresi dalam menerangkan variasi variabel terikat. Nilai koefisien determinasi diperoleh dengan menggunakan formula: (Gujarati, 2006:161).

$R^{2}=1-\frac{\sum e_{i}^{2}}{\sum y_{i}^{2}}$

Nilai koefisien determinasi berada diantara nol dan satu ( $0<\mathrm{R}^{2}<1$ ). Nilai $\mathrm{R}^{2}$ yang kecil atau mendekati nol berarti kemampuan variabel bebas dalam menjelaskan variabel terikat sangat terbatas.

\section{Uji Asumsi Klasiknote}

\section{Uji Heterokedestisitas}

Asumsi pokok dalam model regresi linear klasik adalah bahwa varian setiap disturbance term yang dibatasi oleh nilai tertentu mengenai variabel-variabel bebas adalah berbentuk suatu nilai konstan yang sama dengan $\sigma^{2}$. Inilah yang disebut asumsi heteroskedasticity atau varian yang sama, dengan menggunakan White Test. 


\section{Uji Autokorelasi}

Autokorelasi adalah korelasi (hubungan) yang terjadi diantara anggota-anggota dari serangkaian pengamatan yang tersusun dalam rangkaian waktu (seperti pada data runtun waktu atau time series data) atau yang tersusun dalam rangkaian ruang (seperti pada data silang waktu atau cross-sectional data).

\section{Uji Muktikolinearitas}

Multikolineritas berarti terjadi korelasi linear yang mendekati sempurna antar dua variabel bebas. Uji multikolineritas bertujuan untuk menguji apakah dalam model regresi yang terbentuk ada korelasi yang tinggi atau sempurna diantara variabel bebas atau tidak. Jika dalam model regresi yang terbentuk terdapat korelasi yang tinggi atau sempurna diantara variabel bebas maka model regresi tersebut dinyatakan mengandung gejala multikolinier.

\section{HASIL PENELITIAN DAN PEMBAHASAN}

\section{Hasil Penelitian}

Hasil regresi antar variabel bebas (Ekspor,Impor), dan variabel terikat (Cadangan Devisa) maka digunakan data sekunder yang bersumber dari Bank Indonesia periode 1985 sampai 2011. Data sekunder tersebut diestimasikan dengan analisis regresi berganda seperti yang sudah dijelaskan pada bab sebelumnya, dan diolah menggunakan Program Eviews 7.0 untuk uji t, uji $\mathrm{F}$, uji $\mathrm{R}^{2}$ sampai dengan uji asumsi klasik. Dari hasil regresi dapat dibentuk model estimasi sebagai berikut:

Tabel 1. Hasil Estimasi (OLS) Pengaruh Ekspor dan Impor Terhadap Posisi Cadangan Devisa Di Indonesia

\begin{tabular}{|c|c|c|c|}
\hline \multirow[t]{3}{*}{ lcd } & $=-$ & +2.131 & - \\
\hline & 5.084 & $461 \mathrm{lX}$ & 0.91142 \\
\hline & 432 & & $6 \mathrm{lM}$ \\
\hline \multirow[t]{3}{*}{ t-statistik } & & $(9.425$ & $(-$ \\
\hline & & $595) * *$ & 4.10561 \\
\hline & & $*$ & $9) * * *$ \\
\hline
\end{tabular}

$R^{2}=\quad$ F-Statistik $=518.0910$

0.977362

Sumber : Data diolah (2013)

Ket : *** Signifikansi pada $\alpha=1 \%$

Hasil regresi sebelumnya menjelaskan variabel bebas yaitu Ekspor dan Impor terhadap Cadangan Devisa sebagai berikut: (1) Ekspor berpengaruh positif dan signifikan terhadap cadangan devisa. Hal ini ditunjukkan oleh koefisien regresi Ekspor yaitu sebesar $(+2.131461)$. Artinya setiap kenaikan Ekspor sebesar 1 juta US\$ maka cadangan devisa akan naik sebesar 2.131461 juta US\$, ceteris paribus. (2) Impor berpengaruh negatif dan signifikan terhadap cadangan devisa. Hal ini ditunjukkan oleh koefisien regresi Impor yaitu sebesar (0.911416). Artinya setiap kenaikan Impor sebesar 1 juta US\$ maka cadangan devisa akan turun sebesar 0.911416 juta US\$, ceteris paribus.

\section{Uji Signifikansi Simultan (Uji Statistik F)}

Uji F-statistik dilakukan untuk mengetahui apakah variabel bebas secara bersama-sama berpengaruh terhadap variabel tidak bebas. Pengujian ini dilakukan dengan membandingkan nilai $F_{\text {hitung }}$ dengan nilai $F_{\text {tabel }}$ pada derajat kebebasan (n-k-1) dan tingkat signifikansi $(\alpha)$ $1 \%, 5 \%, 10 \%$. Nilai F-tabel dengan derajat kebebasan $(0,01)$ dan $\alpha=1 \%$ adalah 5.61. Dari hasil regresi diketahui bahwa nilai $F_{\text {hitung }}$ adalah 518.0910. Dengan demikian $F_{h i t u n g}$ lebih besar dari nilai $\mathrm{F}_{\text {tabel, }}$ artinya secara bersama-sama variabel Ekspor, Impor berpengaruh signifikan terhadap Cadangan devisa.

\section{Koefisien Determinasi $\left(\mathbf{R}^{\mathbf{2}}\right)$}

Hasil regresi diketahui bahwa nilai $R^{2}$ adalah $0.977362=97.73 \%$ yang berarti bahwa kontribusi dari variabel bebas Ekspor, Impor secara bersama-sama terhadap variasi naik turunya variabel Cadangan devisa adalah sebesar $97.73 \%$, sisanya $2.27 \%$ disumbangkan oleh variabel lain yang tidak termasuk didalam model.

Uji Asumsi Klasik 


\section{Uji Heterokedastisitas}

Tabel 2. Hasil Uji Heteroskedastisitas

$R^{2}=0.374319$

Obs $* R$-squared $=10.10661$

Chi-Squares $\left(X^{2}\right)$ pada $\alpha 1 \%=$

15.08630

Sumber : Data di olah (2013)

Tabel 2 menunjukkan bahwa bahwa koefisien determinasi $\left(\mathrm{R}^{2}\right)$ sebesar 0.374319. Nilai Chi-squares hitung sebesar 10.10661 yang diperoleh dari informasi Obs*R-squared (jumlah observasi dikalikan dengan $\left(\mathrm{R}^{2}\right)$. Di lain pihak, Nilai Chi-squares $\left(\mathrm{X}^{2}\right)$ pada $\alpha=1 \%$ dengan $\mathrm{df}$ sebesar 5 adalah 15.08630. Karena nilai Chisquares hitung $\left(\mathrm{X}^{2}\right)$ lebih kecil dari nilai kritis Chi-squares $\left(\mathrm{X}^{2}\right)$ maka dapat disimpulkan tidak ada masalah heteroskedastisitas.

\section{Uji Autokorelasi}

Tabel 3. Hasil Uji Autokorelasi

$$
\begin{aligned}
& \hline R^{2}=0.100414 \\
& \hline \text { chi squares }\left(X^{2}\right)=2.711184 \\
& \hline \text { nilai }\left(X^{2}\right) \text { pada } \alpha 10 \%=4.60517 \\
& \hline \text { nilai }\left(X^{2}\right) \text { pada } \alpha 5 \%=5.99147 \\
& \hline \text { nilai }\left(X^{2}\right) \text { pada } \alpha 1 \%=9.21034
\end{aligned}
$$

Sumber : Data di olah (2013)

Tabel 3 menunjukkan nilai koefisien determinasinya $\left(\mathrm{R}^{2}\right)$ sebesar 0.100414 . Nilai chi squares hitung $\left(\mathrm{X}^{2}\right)$, sebesar 2.711184 sedangkan nilai $\left(X^{2}\right)$ pada $\alpha=10 \%, \alpha=5 \%, \alpha=1 \%$ dengan df sebesar 2. karena nilai chi squares hitung $\left(X^{2}\right)$ lebih kecil dari pada nilai chi- squares $\left(\mathrm{X}^{2}\right)$, maka dapat disimpulkan model tidak mengandung masalah autokorelasi.

\section{Uji Multikolinieritas}

Tabel 4. Hasil Uji Multikolinieritas

\begin{tabular}{|c|c|c|}
\hline Variabel & $R^{2}$ Hitung & $R^{2}$ \\
\hline $\mathrm{IX}^{2}$ & 0.971619 & 0.977362 \\
\hline
\end{tabular}

\begin{tabular}{|c|c|c|}
\hline $\mathrm{I}_{\mathrm{M}}$ & 0.971619 & 0.977362 \\
\hline
\end{tabular}

Sumber : Data di olah (2013)

Tabel 4 menunjukkan hasil analisis uji multikolinieritas di atas terlihat bahwa $\mathrm{R}^{2}$ statistik lebih kecil dari $\mathrm{R}^{2}$ model utama. Hal ini menunjukkan bahwa $\mathrm{H}_{0}$ diterima. Dengan diterimanya $\mathrm{H}_{0}$ berarti tidak terdapat masalah multikolinearitas.

\section{Pembahasan}

\section{Analisis Ekonomi Cadangan Devisa di Indonesia}

Ekspor merupakan upaya dalam menjalankan penjualan komoditas yang kita miliki kepada bangsa lain atau negara asing sesuai dengan ketentuan pemerintah dengan mengharapkan pembayaran dalam valuta asing. Berdasarkan hasil estimasi dan penelitian terdahulu, hal ini telah sesuai dengan teori yang menyatakan bahwa jika ekspor meningkat maka jumlah cadangan devisa yang dimiliki akan ikut meningakat sehingga persediaan impor dalam beberapa bulan berikutnya akan tercukupi dan akan memperbesar kemampuan negara tersebut melakukan transaksi ekonomi. Berkaitan dengan pengaruh ekspor. Impor juga memiliki pengaruh terhadap cadangan devisa. impor adalah perdagangan dengan cara memasukkan barang dari luar negeri ke dalam wilayah Indonesia. Impor mempunyai sifat yang berlawanan dengan ekspor. Kalau ekspor dapat dikatakan sebagai faktor "injeksi", maka impor justru merupakan "kebocoran" dalam pendapatan nasional. Berdasarkan hasil estimasi, hal ini telah sesuai dengan teori yang menyatakan bahwa semakin tinggi nilai impor maka akan mengurangi persediaan cadangan devisa.

\section{PENUTUP}

\section{Kesimpulan note}

Hasil analisis data yang telah dilakukan dapat diambil kesimpulan bahwa secara simultan maupun secara parsial variabel ekspor dan impor berpengaruh signifikan terhadap cadangan devisa di Indonesia. Artinya, jika ekspor naik 
maka posisi cadangan devisa akan naik dan jika impor naik maka posisi cadangan devisa akan turun.

\section{Saran}

Hasil penelitian yang telah dilakukan, maka saran yang diberikan :

Ekspor Indonesia harus ditingkatkan, pemerintah dapat memberikan kebijakankebijakan kepada masyarakat khususnya yang akan melakukan ekspor, agar mendapat kemudahan dalam memenuhi syarat melakukan ekspor.

Pemerintah harus menekan pertumbuhan impor, Misalnya dengan cara mengurangi impor produk-produk bermerek dan mengimpor bahanbahan baku yang nantinya akan dipergunakan untuk keperluan ekspor.

Untuk penelitian yang akan dilakukan selanjutnya untuk menambah variabel- variabel lain, serta menambahkan jangka waktu penelitian dengan harapan hasil yang diperoleh dapat lebih baik.

\section{DAFTAR PUSTAKA}

Gandhi, Dyah Virgoana. 2006. Pengelolaan Cadangan Devisa di Bank Indonesia. PPSK. Jakarta.

Gujarati, Damonar N. 2006. Dasar-dasar Ekonometrika Jilid 1dan 2 Edisi ketiga. Eirlangga. Jakarta

Halwani, Henra. 2005. Ekonomi Internasional dan globalisasi Ekonomi

Juniantara., Budhi. 2011. Pengaruh Ekspor, Impor Dan Kurs Terhadap Cadangan Devisa. Bali.

Sukirno, Sadono. 2008. Makro Ekonorni Teori Pengantar, PT. Raja Grafindo Persada, Jakarta.

Suliyanto. 2011. Ekonometrika Terapan: Teori dan Aplikasi dengan SPSS. CV. Andi Offset.

Sumodiningrat. 2007. Ekonometrika Pengantar. Edisi Kedua. BPFE. Yogyakarta. 